\title{
Rapid Detection of Heavy Metals with the Response of Carotenoids in Daucus Carota
}

\author{
Ling Shing Wong and Chieh Wean Choong
}

\begin{abstract}
In this paper, a rapid detection method for heavy metals $(\mathrm{Cu}, \mathrm{Pb}$ and $\mathrm{Zn})$ is reported. The method was based on the response of natural cell-bounded carotenoids in Daucus carota to short term exposure of heavy metals. The cells were cultured for 90 days in dark. The presence of carotenoids in cells was confirmed spectrometrically with optical density (OD) measured at $\lambda=450 \mathrm{~nm}$. The responses of the cells to $0.01,0.10$, and $1.00 \mathrm{ppm}$ of heavy metals were confirmed by the increase of OD after the short term exposure, with the lowest detection were recorded at $0.01,0.10$, and $0.01 \mathrm{ppm}$ respectively. The $O D$ increase might be a result of the synthesis of carotenoids, which was probably triggered by the increase of oxidative stress. With an average optimum response time of $\mathbf{4 0}$ minutes, the cell could be potentially utilized in biosensor.
\end{abstract}

Index Terms-Biosensor, Daucus carota, natural cell-bounded carotenoids, heavy metal.

\section{INTRODUCTION}

Pollution is a worldwide crisis. Due to the overwhelming number of sample analysis and practical consideration, many scientific analysis tools have been developed for rapid detection of pollutants.

Whole cell biosensors offer an alternative way of detection by utilizing biochemical responses of cell towards pollutants such as heavy metals. The biochemical responses can be detected by transducers and then transformed into digital outputs. The correlation between the biochemical responses and digital outputs can be used to detect the heavy metals, either quantitatively, or qualitatively.

So far, detection of biochemical responses such as the chlorophyll fluorescence [1]-[3], oxygen production, enzyme activities [4], and bioluminescence have been reported. The colour pigment which has been extensively studied is the chlorophyll. As a light harvesting pigment, the inhibition of photo-phosphorylation by heavy metals will result in the increase of fluorescence [5], [6]. However, utilization of other types of widely available natural cell-bounded pigments such as carotenoids in biosensor application is lacking.

Carotenoids are linear polyenes which can be synthesized by many photosynthetic organisms and therefore the most widely distributed accessory pigments [7]. In deciduous trees, the pigments are responsible for the yellowish to red fall colours, as well as for the colour of carrots. In plants, carotenoids serves as light harvesting pigments, which have

Manuscript received July 1, 2013; revised November 3, 2013.

L. S. Wong and C. W. Choong are with Inti International University, Nilai, Negeri Sembilan, Malaysia. They are also with the Faculty of Science, Technology, Engineering and Mathematics (e-mail: lingshing79@yahoo.com.sg, chiehwean.chong@newinti.edu.my). excellent absorption of the wavelength between $400 \mathrm{~nm}$ to $480 \mathrm{~nm}$. Besides, carotenoids help to reduce the production of reactive oxygen species by absorbing the energy from chlorophyll and dissipate the energy through internal conversion as heat [8]. In the context of reducing the reactive oxygen species, carotenoids serves as non-enzymatic antioxidants which protect the plants from the destruction of the oxidative stress [9].

Heavy metals have been reported as photosynthesis inhibitors [10]-[14] by uncoupling the oxidation-reduction sites in photosystems. The presence of heavy metals increases the amount of reactive oxygen species and at the same time increase oxidative stress in plants [15]. Thus, the reaction of natural cell-bounded carotenoids to the exposure of heavy metals is well anticipated.

Dar et al. [16] reported that carotenoids content of Triticum aestivum L. reduced after being exposed to heavy metals for three. On the other hand, Pinto et al. [17] reported that the exposure of heavy metals to Gracilaria tenuistipitata for 6 induced the synthesis of carotenoids. The response has been utilized in environmental pollutants detection. Rahman et al. [18] depicted a possible way using cyanobacteria contained carotenoids in biosensor application, with the incubation time of 10 days. Yoshida et al. [19], [20] utilized the production of carotenoids in mutated purple bacteria Rhodopseudomonas palustris no. 7 in heavy metal detection, with the increase of carotenoids detected in 6 hours of inhibition. However, the practicality of these applications has been limited either by the usage of transgenic organisms or the long exposure time required to enable the detection.

In this paper, the responses of carotenoids contained in $D$. carota cells in suspension to $\mathrm{Cu}, \mathrm{Pb}$ and $\mathrm{Zn}$ are reported. The responses could be detected within 60 minutes of exposure to heavy metals, which was faster than previously reported.

\section{Methodology}

\section{A. Chemicals and Glassware}

The chemicals used for the preparation of MS medium were purchased from R \& M Marketing, Sigma-Aldrich, Systerm, and Phyto Technology Laboratories. All the glassware used in this experiment was autoclaved with $121^{\circ} \mathrm{C}$ and $15 \mathrm{psi}$ for 15 minutes. All the equipment used in cell cultured was sterilized with $70 \%$ ethanol before use.

\section{B. Cell Preparation}

D. carota taproot was sliced into discs with thickness of approximately $1 \mathrm{~cm}$, immersed in $70 \%$ ethanol for $30 \mathrm{~s}$ and agitation in sterilant $(0.525 \% \mathrm{NaOCl}, 0.05 \%$ Triton $\mathrm{X}-100)$ for 25 minutes. It was rinsed thrice with distilled water 
afterward. The discs were excised with cambium layer in the middle. These processes were conducted in sterile Laminar Flow Cabinet (ESCO).

These explants were cultured on MS medium [21] with 25 $\mathrm{g} / \mathrm{L}$ sucrose, $2.2 \mathrm{~g} / \mathrm{L}$ gelrite and $1 \mathrm{mg} / \mathrm{ml} \mathrm{2,}$ 4-dichlorophenoxyacetic acid. The culture was maintained in dark condition for 60 days in the culture room.

The explants were sub-cultured after 60 days and incubation at $25^{\circ} \mathrm{C}$ for in dark for 30 days. The resulting liquid with cell suspension was filtered to minimize the number of clumps. Centrifugation was conducted using Heraeus Megafuge 10R (Thermo Electron Corporation) to collect the cells. The cell pellet was resuspend in MS broth medium and ready to be used.

\section{The Absorbance of Carotenoids}

A volume of $2 \mathrm{~mL}$ of $D$. carota cell suspension was transferred into a cuvette, followed by spectrophotometry determination of optimized wavelength, as described by Wong and Choong [22]. The wavelength with the highest OD was identified at $450 \mathrm{~nm}$. The wavelength was used to determine the change in carotenoids content in the experiment.

\section{Heavy Metals Detection}

The stock solutions of $\mathrm{Cu}$ with concentrations of $10.0 \mathrm{ppm}$ and $0.1 \mathrm{ppm}$ were prepared. Other solutions concentrations ( 0.01 and $1.00 \mathrm{ppm})$ of $\mathrm{Cu}$ solution used in the experiment were prepared by the dilution of the stock solutions.

To study the responses of the cells to $1 \mathrm{ppm}$ of $\mathrm{Cu}, 0.2 \mathrm{~mL}$ of $10 \mathrm{ppm} \mathrm{Cu}$ stock solution was transferred into $1.8 \mathrm{~mL}$ medium containing $D$. carota cell suspension, to make a final concentration of $1 \mathrm{ppm}$ of $\mathrm{Cu}$. OD readings were taken before the exposure. OD readings were taken again after 20,40 and 60 minutes of exposure to $\mathrm{Cu}$. The experiment was repeated using $\mathrm{Cu}$ with concentration of $0.10 \mathrm{ppm}$ and $0.01 \mathrm{ppm}$ respectively in triplicate.

The same procedure was then applied to the tests on $\mathrm{Pb}$ and $\mathrm{Zn}$. All the experiments on heavy metals detection were conducted in triplicates.

\section{E. Data Analysis}

The percentage of OD increment was calculated as follows:

Percentage $(\%)$ of OD increment $=$

$\left[\left(\mathrm{OD}_{1}-\mathrm{OD}_{0}\right) / \mathrm{OD}_{0}\right] \times 100 \%$

where,

$\mathrm{OD}_{0}=\mathrm{OD}$ before the exposure to heavy metals

$\mathrm{OD}_{1}=\mathrm{OD}$ after the exposure to heavy metals

The data obtained from responses of $D$. carota to heavy metals over 60 minutes of exposure were compared to the responses of cells without heavy metals (blank, with $1.8 \mathrm{~mL}$ of cell culture and $0.2 \mathrm{~mL}$ of distilled water). All the analysis in this experiment was conducted using Microsoft Excel.

\section{RESULTS AND DISCUSSION}

Spectrometry analysis on $D$. carota cells showed highest absorbance at $450 \mathrm{~nm}$, which was in agreement with the absorbance of carotenoids [23], [24], thus the presence of carotenoids was evidence. The culture of taproot cell was conducted in dark condition, in order to promote the synthesis of carotenoids, on the other hand inhibiting the synthesis of chlorophylls [25], [26].

The response of carotenoids to $\mathrm{Cu}$ is illustrated in Fig. 1. The exposure raised the absorbance for all concentration of $\mathrm{Cu}$ tested. The maximum OD was yielded at 40 minutes of exposures.

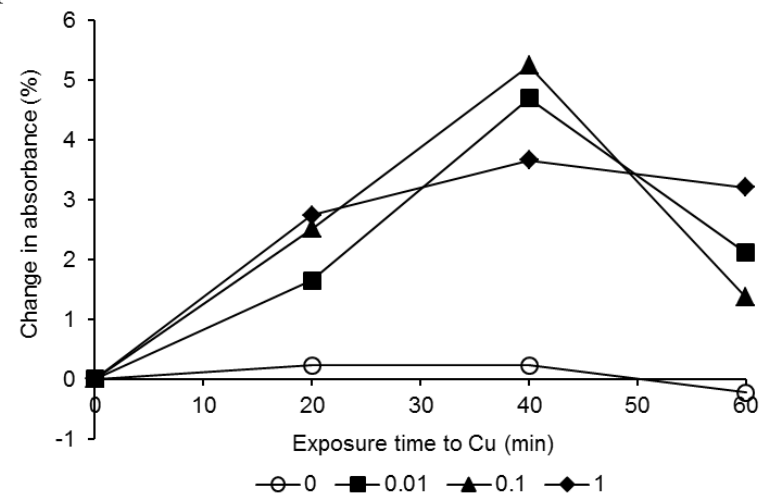

Fig. 1. Response of carotenoids as indicated by the percentage of change in absorbance over time at various concentration of $\mathrm{Cu}$.

D. carota bounded carotenoids showed similar trend to the exposure tests on $\mathrm{Pb}$ and $\mathrm{Zn}$, as depicted in Fig. 2 and Fig. 3. Maximum absorbance yielded predominately at 40 minutes. The cell showed observable response to $\mathrm{Cu}$ and $\mathrm{Zn}$ tested at $0.01 \mathrm{ppm}$. However, the response of carotenoids to $\mathrm{Pb} 0.01$ ppm has no significant difference from blank. This indicated that the sensitivity of the cell to $\mathrm{Pb}$ was lower than $\mathrm{Cu}$ and $\mathrm{Zn}$. The result was different from the research done on cyanobacteria by Wong et al. [2] showing the photosynthetic organism was more sensitivity to $\mathrm{Pb}$ than $\mathrm{Cu}$.

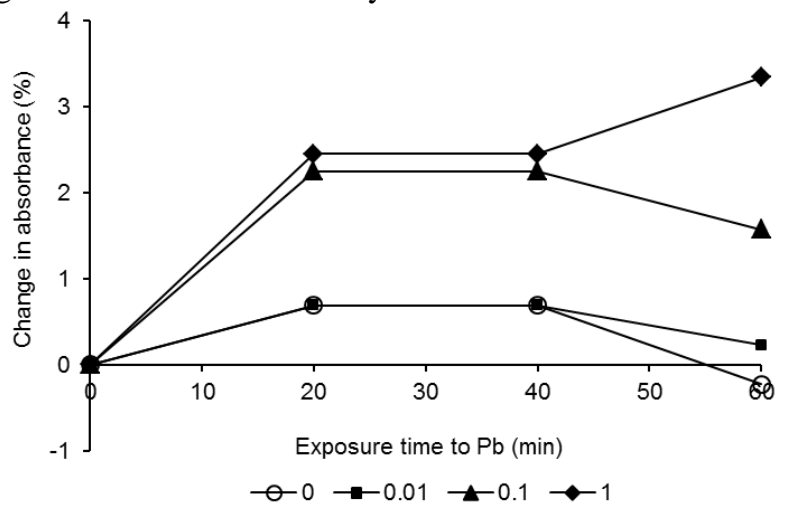

Fig. 2. Response of carotenoids as indicated by the percentage of change in

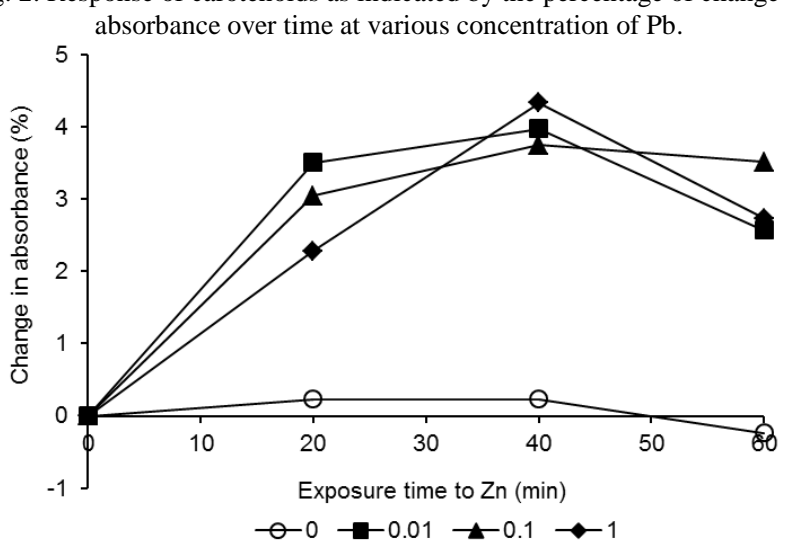

Fig. 3. Response of carotenoids as indicated by the percentage of change in absorbance over time at various concentration of $\mathrm{Zn}$. 
$\mathrm{Cu}$ is a micronutrient which is essential to photosynthetic organisms in small amount in ionic form. In plants, $\mathrm{Cu}$ is required in metalloprotein synthesis. Metalloprotein is an important element in electron transfer of photosynthetic redox [27]. However, $\mathrm{Cu}$ will affect cell's metabolism in high concentration [28]. $\mathrm{Pb}$ is non-beneficial and non-functional element for photosynthetic organisms. Low concentration of $\mathrm{Pb}$ will trigger the toxicity effect where inhibition of photosynthesis is evidence [29], [30]. Thus, the toxicity effect of $\mathrm{Cu}$ is always expected to be lower than $\mathrm{Pb}$. However, $D$. carota cell used in this experiment responded otherwise.

The responses of the cell on 40 minutes of exposure to various concentrations of heavy metals after noise filtration are shown in Fig. 4. Although $\mathrm{Cu}$ induced the highest response with a glance, statistical test showed no significant difference $(\mathrm{p}<0.05)$ between $\mathrm{Cu}$ and $\mathrm{Pb}$, as well as $\mathrm{Zn}$ and $\mathrm{Pb}$.

The biosensors constructed for environmental application needs to be sensitive and able to detect analytes in short period of time [31]. In this experiment, the cell showed good response towards heavy metals. The cell was able to detect $0.01-1.00 \mathrm{ppm}$ of $\mathrm{Cu}$ and $\mathrm{Zn}$, as well as $0.10-1.00 \mathrm{ppm}$ of $\mathrm{Pb}$. The short response time of 40 minutes was a good indication that the cell could be used as biological component in a biosensor. Average standard deviations for the tests on $\mathrm{Cu}$, $\mathrm{Pb}$, and $\mathrm{Zn}$ were $\pm 4.90 \%, \pm 4.26 \%$, and $\pm 1.95 \%$ respectively $(n=3)$.

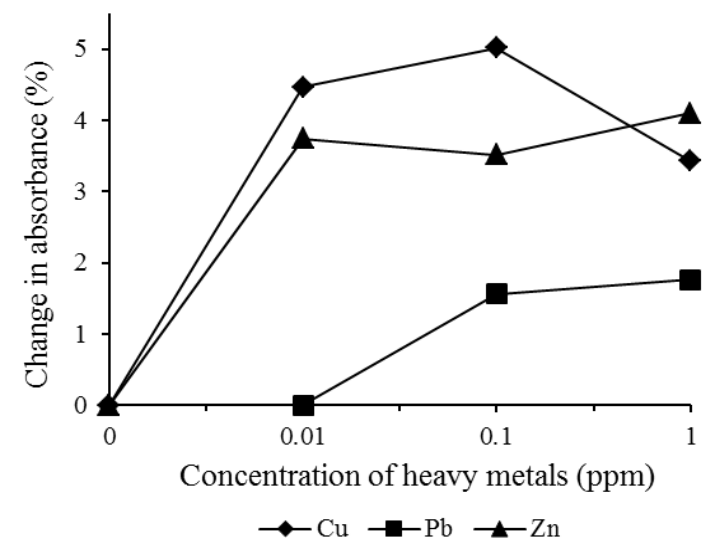

Fig. 4. Response of carotenoids as indicated by absorbance at $450 \mathrm{~nm}$ against various concentrations of heavy metals $(\mathrm{Cu}, \mathrm{Pb}$ and $\mathrm{Zn})$ at 40 minutes exposure time.

Although the cell showed good sensitivity and reproducibility in the tests with a few types of heavy metals, further work is required to incorporate the cell into a biosensor. The factors which influence the response of cell, such as the condition of the culture, the number of cell to be used in detection, the detection condition such as $\mathrm{pH}$ are yet to be studied [2], [3], [32]. The cells cultured respond differently in different growth stage, while different number of cells used affects the signal produced as well. According Wong et al. [5], the increase of the signal produced was positively proportionate to the number of cells used within a limit, whereas the increase of cells used after the limit diminished the signal produced.

The immobilization of cells will be tested as it is an important process in biosensor construction, which helps to increase the performance of biosensor by bringing the biocomponent closer to the transducer [3], [5]. The reports show that chitosan and acrylamide [33], poly-2-hidroxy-ethyl-methacrylate [5], alginate and silica [34], and agarose [35] have been utilized in biosensor construction as immobilizing agents. This work will be continued by immobilization of $D$. carota cells on a suitable support medium by a selected immobilizing agent. Agarose might be a good candidate for its natural derived composition and the ability to polymerize under low temperature.

The operation environment of the biosensors affects the respond of the cells, which has to be studied as well. $\mathrm{pH}$ is most widely studied factor, as bioconponents are affected by the $\mathrm{pH}$ of the environment [32], [36].

Besides, the stability of immobilized cells will have to be tested. The stability of biosensors is important feature to determine the storability of the biocomponent over a period of time. It is a normal trend where biocomponent deteriorates over a period of storage time [5], [36]. The higher the stability, the better the biosensor retains the signal produced over a period of time of storage. The storability reflects the practicality of the biosensor as well.

\section{CONCLUSION}

The spectrometric response of $D$. carota to heavy metals at the absorbance of $450 \mathrm{~nm}$ showed that carotenoids can be used as biological element in biosensor, with the detection limits at $0.01-0.1 \mathrm{ppm}$ and the response time of 40 minutes. However, more work has to be done in order to fully understand the mechanism behind the increment of absorbance at $450 \mathrm{~nm}$.

\section{REFERENCES}

[1] S. F. D' Souza, "Review microbial biosensors," Biosensors and Bioelectronics, vol. 16, pp. 337-353, 2003.

[2] L. S. Wong, Y. H. Lee, and S. Salmijah, "The fluorometric response of cyanobacteria to short term exposure of heavy metal," Advances in Environmental Biology, vol. 6, pp. 103-108, 2012.

[3] L. S. Wong, Y. H. Lee, and S. Salmijah, "Toxicity biosensor for the evaluation of cadmium toxicity based on photosynthetic behavior of cyanobacteria anabaena torulosa," Asian Journal of Biochemistry, vol. 3, pp. 162-168, 2008.

[4] K. Takayama, S. Suye, Y. Tanaka, A. Mulchandani, K. Kuroda, and M. Ueda, "Estimation of enzyme kinetic parameters of cell surface-dsiplayed organophosphorus hydrolase and construction of a biosensing system for organophosphorus compounds," Analytical Sciences, vol. 27, pp. 823-826, 2011.

[5] L. S. Wong, Y. H. Lee, and S. Salmijah, "Performance of a cyanobacteria whole cell-based fluorescence biosensor for metal and pesticide detection," Sensors, vol. 13, pp. 6394-6404, 2013.

[6] L. S. Wong, Y. H. Lee, and S. Salmijah, "Whole cell biosensor using anabaena torulosa with optical transduction for environmental toxicity evaluation," Journal of Sensors, vol. 2013, ID. 567272, 2013.

[7] J. G. Voet and C. W. Voet, Biochemistry, 4th Ed., United States of America: John Wiley \& Sons Inc., 2011, ch. 25, pp. 905-908.

[8] R. H. Garrett and C. M. Grisham, Biochemistry, 4th Ed. United States of America: Brooks/Cole Cengage Learning, 2010, ch. 21, pp. 634.

[9] S. McElroy and D. A. Kopsell, "Physiological role of carotenoids and other antioxidants in plants and application to turfgrass stress management," New Zealand Journal of Crop and Horticultural Sciences, vol. 37, pp. 327-333, 2009.

[10] N. Atal, P. P. Saradhi, and P. Mohanty, "Inhibition of the chloroplast photochemical reaction by treatment of wheat seedlings with low concentrations of cadmium: analysis of electron transport activities and changes in fluorescence yield," Plant and Cell Physiology, vol. 32, pp. 943-951, 1991. 
[11] H. Clijsters and V. V. Assche, "Inhibition of photosynthesis by heavy metals," Photosynthesis Research, vol. 7, pp. 31-40, 1985.

[12] M. Kimimura and S. Katoh, "Studies on electron transport associated with photosystem II functional site of plastocyanin: inhibitory effects of $\mathrm{HgCl}_{2}$ on electron transport and plastocyanin in chloroplasts," Biochimica et Biophysica Acta-Bioenergetics, pp. 279-292, 1972.

[13] Z. Krupa, G. Öquist, and P. A. N. Huner, "The effects of cadmium on photosynthesis of phaseolus vulgaris - a fluorescence analysis," Physiology of Plant, vol. 88, pp. 626-630, 1993.

[14] V. Yatsenko, "Determining the characteristics of water pollutants by neural sensors and pattern recognition methods," Journal of Chromatography A, vol. 722, pp. 233-243, 1996.

[15] J. A. Azevedo and R. A. Azevedo, "Heavy metals and oxidative stress: where do we go from here?" Communication in Biometry and Crop Science, vol. 1, pp. 135-138, 2006.

[16] S. H. Dar, R. K. Agnihotri, R. Sharma, and S. Ahmad, "Nickel and lead induced variations in pigment composition of triticum aestivum L.," Research Journal of Agricultural Sciences, vol. 1, pp. 128-131, 2010.

[17] E. Pinto, A. P. Carvalho, K. H. Morais, Cardozo, F. Xavier, Malcata, F. Maria dos, Anjos, and P. Colepicolo, "Effects of heavy metals and light levels on the biosynthesis of carotenoids and fatty acids in the macroalgae gracilaria tenuistipitata (var. liui Zhang \& Xia)," Brazilian Journal of Pharmacognosy, vol. 21, pp. 349-354, 2011.

[18] M. A. Rahman, K. K. Soumya, A. Tripathi, S. Sundaram, S. Singh, and A. Gupta, "Evaluation and sensitivity of cyanobacteria, nostoc muscorum and synechococcus PCC 7942 for heavy metals stress - a step toward biosensor," Toxicological and Environmental Chemistry, vol. 93, pp. 1982-1990, 2011.

[19] K. Yoshida, D. Yoshioka, K. Inoue, S. Takaichi, and I. Maeda, "Evaluation of colors in green mutants isolated from purple bacteria as a host for colorimetric whole-cell biosensors," Applied Microbiology and Biotechnology, vol. 76, pp. 1043-1050, 2007.

[20] K. Yoshida, K. Inoue, Y. Takahashi, S. Ueda, K. Isoda, K. Yagi, and I. Maeda, "Novel carotenoid-based biosensor for simple visual detection of arsenite: characterization and preliminary evaluation for environmental application," Applied and Environmental Microbiology, vol. 74, pp. 6730-6738, 2008.

[21] T. Murashige and F. Skoog, "A recised medium for rapid growth and bio assays with tobacco tissue cultures," Physiologia Plantarum, vol. 15, pp. 173-497, 1962.

[22] L. S. Wong and C. W. Choong, "The responses of natural cell-bounded carotenoids to short term exposure of heavy metals," International Proceedings of Chemical, Bioloagical and Environment Engineering: Environment and Bioscience, vol. 44, pp. 103-108, 2012.

[23] D. Ortiz, T. Sánchez, N. Morante, H. Ceballos, H. Pachón, M. C. Duque, A. L. Chávez, and A. F. Escobar, "Sampling strategies for proper quantification of carotenoid content in cassava breeding," Journal of Plant Breeding and Crop Science, vol. 3, pp. 14-23, 2011.

[24] R. G. A. Oliveira, M. J. L. Carvalho, R. M. Nutti, L. V. J. Carvalho, and W.G. Fukuda, "Assessment and degradation study of total carotenoid and $\beta$-carotene in better yellow cassava (manihot esculenta crantz) varieties," African Journal of Food Science, vol. 4, pp. 148-155, 2010

[25] A. Rodríguez-Villalón, E. Gas, and M. Rodríguez-Concepción, "Colors in the dark," Plant Signaling \& Behavior, vol. 4, pp. 965-967, 2009.

[26] C. Stange, P. Feutes, M. Handford, and L. Pizarro, "Daucus carota as a novel model to evaluate the effect of light on carotenogenic gene expression," Biology Research, vol. 41, pp. 289-301, 2008.

[27] C. Cervantes and F. Gutierrez-Corona, "Copper resistance mechanisms in bacteria and fungi," FEMS Microbiology Review, vol. 14, pp. 121-138, 1994
[28] M. N. V. Prasad, P. Malcc, A. Waloszck, M. Bojko, and K. Strzalka, "Physiological responses of lemna trisulca L. (duckweed) to cadmium and copper bioaccumulation," Plant Science, vol. 161, pp. 881-889, 2001.

[29] F. A. Bazzaz, W. R. Carlson, and G. L. Rolfe, "The effect of heavy metals on plants: part I- inhibition of fas exchange in sunflower by $\mathrm{Pb}$, Cd, Ni, and Ti," Environmental Pollution, vol. 7, pp. 241-246, 1974.

[30] P. J. Ralph and M. D. Burchett, "Photosynthetic response of halophila ovalis to heavy metal stress," Environmental Pollution, vol. 103, pp. 91-101, 1998

[31] K. R. Rogers, "Biosensor for environmental application," Biosensors and Bioelectronics, vol. 10, pp. 533-541, 1995.

[32] C. Védrine, J. C. Leclerc, C. Durrieu, and C. Tran-Minh, "Optical whole-cell biosensor using chlorella vulgaris designed for monitoring hebicides," Biosensors and Bioelectronics, vol. 18, pp. 457-463, 2003.

[33] I. S. P. Savizi, H. R. Kariminia, M. Ghadiri, and R. Roosta-Azad, "Amperometric sulfide detection using coprinus cinereus peroxidase immobilized on screen printed electrode in an enzyme inhibition based biosensor," Biosensor and Bioelectronics, vol. 35, pp. 297-301, 2012

[34] Y. Ferro, M. Perullini, M. Jobbagy, S. A. Bilmes, and C. Durrieu, "Development of a biosensor for environmental monitoring based on microalgae immobilized in silica hydrogels," Sensors, vol. 12, pp. 16879-16891, 2012.

[35] H. J. Shin, "Agarose-gel-immobilized recombinant bacterial biosensors for simple and disposable on-site detection of phenolic compounds," Applied Microbiology and Biotechnology, vol. 93, pp. 1895-1904, 2012.

[36] D. Ivekonić, M. Japec, M. Solar, and N. Zivkonić, “Amperometric uric acid biosensor with improved analytical performance based on alkaline-stable $\mathrm{H}_{2} \mathrm{O}_{2}$ transducer," International Journal of Electrochemical Science, vol. 7, pp. 3252-3264, 2012.

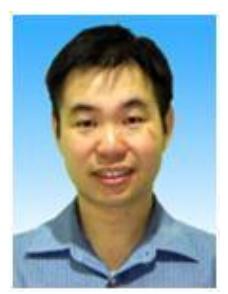

L. S. Wong obtained his Ph.D. in environmental science from the National University of Malaysia. He is an active researcher in the development of biosensors and the assessment of environmental toxicity. His current interest of research includes the development of different parameter of detection for whole cell biosensors, the usage of different colour pigments as reporter groups, and the development of different type of cells to be used in biosensors.

$\mathrm{He}$ is a senior member of Asia-Pacific Chemical, Biological and Environmental Engineering Society (APCBEES). He serves as reviewer in several international journals and international conferences as well. Besides science and technology, he is a proactive researcher in the field of teaching and learning. To date, he has authored more than 30 scientific articles, which have been published in peer-reviewed international proceedings and journals.

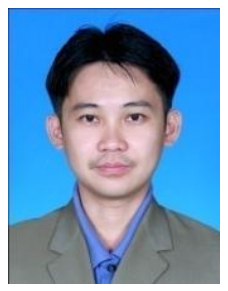

C. W. Choong obtained his Ph.D. from University Putra Malaysia. He is a senior lecturer in INTI International University for more than 5 years and involves in plant biotechnology research for more than 14 years. He was familiar with molecular biology research, especially on study of plant gene expression at RNA level. His present research involves medium formulation and tissue culture of endangered orchid species. 